\title{
Role Playing Method: Learning to Avoid Cheating
}

\author{
Siti Khorriyatul Khotimah \\ Psychology Departement \\ Islamic State University (UIN) Sunan Ampel Surabaya \\ khotim_psi@yahoo.com
}

\begin{abstract}
Nowadays a lot more teachers and educators realize that cheating increase in academic settings. Students cheat in doing their homework and exam by reading books or ask their friends. This research aim is to test the influence of role playing method toward cheating on undergraduate students. The type of this research is Quasi Experimental Research using Non Equivalent Control Group Post-test Only Design. The subjects are $3^{\text {th }}$ undergraduate student of Psychology Program at UIN Sunan Ampel Surabaya. This research take 86 subjects, divided into experimental and control groups. The treatment, role-playing method in learning given to experimental group in 3 sessions. The measurement of cheating is using Cheating Scale, which measure cheating in 3 aspects; attitude, tendency and behaviour. The test result through t-test shows that there is difference of cheating on experiment group and control group. It means that role playing method in learning influence student's cheating.
\end{abstract}

Keywords-role playing method, cheating

\section{INTRODUCTION}

Nowadays, it is almost impossible for us to read a newspaper or watch news without any report on dishonest behavior in different forms [1]. At school, one of dishonest behavior appears as cheating. In Indonesia, one of cheating case was mass cheating in SDN Gadel II, where Mrs. Siami reported student's cheating behavior at the National Final Examinations [2]. The next phenomenon of mass cheating was the police findings about cheating at National Final Examination at several schools [3].

Cheating is a tendency to use or attempt to use material, information or equipment that are not permitted in academic activities. In this case, including all forms of assigment collected for credit or time. Therefore, cheating behaviors regarding such as using small notes or copying during tests and unpermitted cooperation on tasks outside the classroom [4]. According to Davis et. al,, cheating behavior are all seeking, giving and getting answers or completing academic tasks that is forbidden, imitate or deceive others [5]. Cheating is not only related to the behavior of taking a test in school but also in doing homework that was required as independent task, but done with other person help while the teacher didn't know or the teacher assumed that the student work independently. Cheating behavior includes copying books/ notes for tasks and tests, copying on a small note on tests, and copying other student's answers while working on assignments and exams [6-8]. Cheating is a "violation of rules" in which students demonstrate ability or knowledge that is not true [9]. In this study, cheating define as attitude, tendency and behavior to copying from books/ notes on tasks and tests, copying on a small note on the test, and copying other student's answers while working on assignments and exams.

Some research show that cheating and other academic dishonesty carried out starting from elementary [10-11], high school [12-20]. It showed that students start cheating on elementary to high-grade school and tend to increase in further education.

There are different expectations of academic honesty between students and lecturers [21]. According to Deranek \& Parnther, academic dishonesty in higher education is stemming because of the easy access to information from internet and technology, so the educators must be proactive in their approach to students [22]. In developing the academic honesty, it is very important to have a dialogue between students and faculty. In the reaction of peers, students who saw their friends cheating, show varied responses, including emotional reactions, from opposing to feel sorry . Other reaction is against or feel injustice because they studied and students who do cheat didn't, while their score could be higher. Some felt frustrated because they both do not know what to do with the cheating phenomenon, or simply do not want to be held responsible for it; and the other generally ignore these phenomenon. Students experience anxiety because they do not want to take responsibility on it, but they feel that they shouldn't be, or because of fear of their friends reaction. Other student who empathize tend to receive the cheating because they understand, imagine if they were in that position, and they don't want to report it.

Several studies indicate an attempt to prevent academic dishonesty, including; the use of anti-plagiarism software , the application of cognitive dissonance intervention ; classroom application control technique ; reveal the direct effect of knowledge and attitude toward academic dishonesty. In general, studies that attempt to prevent academic dishonesty can be divided into two, which involves external factors (anti-plagiarism software and classroom control technique) and internal factors (cognitive dissonance intervention and direct knowledge and attitude).

In this study, the author interested in studying the cheating on undergraduate students because some earlier studies showed that at this stage a lot of cheating behavior occurs. This study want to try out an attempt to reduce cheating behavior on undergraduate student. According to Eisenberg, educators and school authorities always try to reduce student cheating behavior [23]. Some suggested steps for the school including; explains the moral standard 
(meaning cheating and its consequences for students), building and directing norms among peers, and build environment that refuses to cheating activity.

One alternative that allows us to do it in learning by engage students in an active discussion, is role playing method. Travis explain that role playing is a technique in a class that is ready to be used by practitioners to increased moral development as the concept of Kohlberg's moral development [24]. According to Joyce and Weil, role playing use in problematic situations for open discussions about values and how they use it in everyday live [25]. This model allows students to study the values as the core of selfgrowth, somewhere the social norms and personal identity and feeling grow together. Joyce and Weil reinforces that role playing direct students to explore the problems of human relations in a way played a role in the situation of the problem and then discuss the regulations. Also for students, to express feelings, behavior, values and problem-solving strategies. Students discuss the cheating behavior through role playing in learning through 3 phases: (1) delineated the problem, (2) acted it out, and (3) discussion.

Joyce and Weil added that role playing is a teaching model that is derived from the individual and social dimention, that it can be used to practice problem-solving strategies and social values develop on students. Through applying a model of role playing in the learning, it is expected that students will be directed to actively discuss the phenomenon of cheating, risks, and efforts to avoid it. Repeatetion treatment is expected to direct them to reduce their cheating. In this study, the author examine the effect role playing method in learning to reduce cheating on undergraduate student.

\section{RESEARCH METHOD}

This is a field experiment research in which the research study in a real situation (reality), by manipulating one or more independent variables in controlled conditions. The research design is Quasi Experimental research, which is an experimental study that approximates the shape of true experiment where there is no relevant control or manipulation of variables, but only in some variables [26]. In this study, to be manipulated is the independent variable, Role Playing Method in Learning with Non-Equivalent Control Group Post-test Only Design. The subject of this study are psychology undergraduate students of UIN Sunan Ampel Surabaya on 2 classes were 86 students. In this design there are two groups: experimental group treated and control group as a comparison group who did not receive treatment. The design as below:

\begin{tabular}{|l|c|c|c|}
\hline Group & Pre-test & Treatment & Post-test \\
\hline $\begin{array}{l}\text { Experimenttal } \\
\text { Group }\end{array}$ & - & $\mathrm{X}$ & $\mathrm{T} 2$ \\
\hline Control Group & - & - & $\mathrm{T} 2$ \\
\hline
\end{tabular}

The dependent variable in this study is cheating. It measured by Cheating Scale in Lickert scale using fivepoint scale, that measure cheating indicators : (1) copying from books/ notes on tasks, (2) copying from books/ notes on tests, (3) copying on a small note on the test, (4) copying other student's answers while working on assignments, and (5) copying other student's answers while working on exams. The questioners are given in 3 aspect of cheating. There are student's attitudes, tendencies, and behavior to cheat. Attitudes means student's agreement or disagreement against cheating behavior committed by others or to themselves, tendencies is related to their plan to cheat, and behavior is the real action to cheat. There are 30 questions distributed in 10 items each aspects. On instrument try out to 99 participants, it was found that according to product moment analysis, all items are valid and can be used. The reliablity test using Cronbach's Alpha show alpha coefisience value 0.935 . It indicates that the items on cheating scale is reliable and can be used.

The independent variable of this study is the role playing method in learning done in 3 phases, namely: ( 1 delineated the problem, (2) acted it out, and (3) discussion. In this case the issue to be discussed is cheating on academic setting. Because of the importance of role playing method's manual as the treatment in this study, the researcher developed a module of role playing learning method. Role playing activities done in class discussion sessions with those 3 phases guided by lecturers. Activities and themes adapted to the lecture material and assignments. In general, the theme of each activities are:

$1^{\text {st }}$ day: academic honesty in research

$2^{\text {nd }}$ day: various academic honesty studied and observed

$3^{\text {rd }}$ day: discussion about cheating the experience and solutions

Lecture materials in all groups (experiment and control group) are the same, the difference is the activities of students and lecturer in classroom discussions and themes of the journal / research assignment. Activity in the experimental group discussions conducted by applying the role playing method in learning, while the control group with a class discussion. On the assignment of searching and reviewing journals/ research, the experimental group tasked with seeking and reviewing journals /research on the theme of academic honesty, and the control group seeking journal / research with free theme.

The data collected after the treatments. Normality tests previously performed to the result of cheating on the experimental group and the control group to ensure the data are normally distributed or not. Normality test results in the experimental group with a significance value of 0.582 ( $\mathrm{sig}>$ 0.05 ) and the control group with a significance value of 0.343 ( $\mathrm{sig}>0.05$ ), shows the normal distribution of data. Then analyzes the data to reveal whether the role playing method in learning influence student's cheating can be done by t-test. 
III. RESULT

The t-test result as below:

Paired Samples Test

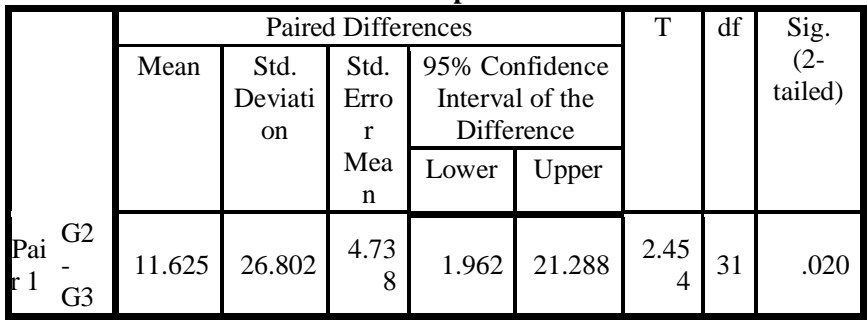

The $\mathrm{t}$ value between 2 groups is equal to 2.454 with a significance value of $0.020(<0.05)$. It shows that there was significant difference between the experimental group and control group postets. It means that there is an influence of role playing method in the learning to student's cheating. Hypothesis "role playing method in learning influences student's cheating" is acceptable.

\section{DISCUSSION}

The finding indicate that there is difference of cheating on experiment group and control group. It means role playing method in the learning influence student's cheating

The role playing method in learning influence students cheating because of some reason. First, since the beginning, the university principals support this research. They hope it can reduce undergraduate student's cheating. This support is an importnace factors, such as Eisenberg said that educators and schools constantly strive to reduce student cheating behavior . Tas \& Tekkaya also revealed that one of factors affects the cheating behavior is classroom goal structure . The seriousness of the university efforts to reduce this cheating behavior is the foundation to build a more honest environment.

Second, the selection of treatment. Role playing methods in learning is the right choice in teaching the values of honesty, to avoid cheating behavior. In order to reduce cheating behavior, Eisenberg suggested several measures for school practies including; explains the moral standard (meaning cheating and its consequences for students), building and directing norms among peers, and build environment that refuses to cheat activity [23]. Role playing method support all that practices. According Travis, role playing is a technique in a class that is ready to be used by practitioners to improve the moral development on Kohlberg's concept [27]. Teachers can help students to develop it.

Third, students actively involved in learning. According to Joyce and Weil role playing methods directs students to explore the problems of human relations in a way they play a role in the situation of the problem and then discuss the regulations [25]. At the time of the discussion roles, students openly expressed their opinion that is not only showed the desire to avoid cheating behavior, but also supports the cheating behavior as a necessity, solidarity even as the ethics of friendship. In the reaction of peers, students who witnessed her friends cheating, show varied responses, including emotional reactions, from opposing to feel sorry [17]. Although students argue cheating as something unpleasant, and they admit to doing cheating but never caught [8]. It shows that peer support is very important in cheating behavior. That is why as an effort to reduce cheating behavior, we need to involve peers. Through interaction in discussions, students develop their awareness, initiatif and motivation.

Fourth, this openness makes it possible for students who originally supported cheating, with a series of discussions evolved into tend to avoid cheating. Direct knowledge of their friends cheating behavior is a major predictor of cheating behavior, followed by neutralizing the tendency to conform and respects. Role playing directs students to explore the problems of human relations in a way played a role in the situation of the problem and then discuss the rules. This is appears in the last discussion where most students are more openly expressed disapproval of the behavior of cheating. Some student with disagreement is then grown on the discussion about the values of honesty and the importance of avoiding cheating behavior.

Fifth, the behavior changes that known from the reduce on cheating behavior after trearment is caused from changes ini their way of thinking. The implementation of role playing method on learning, related to constructivism approach. As Joyce and Weil said that together, students can explore feeling, attitudes, values, and problem solving strategies [25]. Through role playing activities students share their peers, strenghten honesty values and develop problem solving skill based on problem sampled. As constructivism approach their knowledge is constructed by learner, not accept passively from environment [27].

\section{CONCLUSION}

The finding shows that role playing method in the learning influence student's cheating. Based on this research process, result and discussion, we propose some considerations. Suggestions related to theoretical usefulness of scientific research are: (1) time series experiment with the findings of this study as treatment model is needed to test the consistency, and (2) develop role playing method based on 9 stage of Shaftel model. Practically, it is recomended: (1) to teachers/ lecturers to use and develop this learning model, and (2) to the principal in order to disseminate the results of research.

\section{ACKNOWLEDGEMENT}

This research has received funding from DIPA UIN Sunan Ampel Surabaya on 2013. Publication of the presented results has received funding from UIN Sunan Ampel Surabaya 2016

\section{REFERENCE}

[1] Mazar, N., Amir, On \& Ariely D, The Dishonesty of Honest People : A Theory of Self-Concept Maintenance, Journal of Marketing research, 3-644 Vol XLV, 63

[2] Jawa Pos, Newspaper, June $12^{\text {th }}-16^{\text {th }} 2011$ 
[3] Jawa Pos, Newspaper, May $24^{\text {th }} 2014$

[4] Whitley, B. E., \& Spiegel P. K. 2002, Academic Dishonesty, an Educators Guide, Larencce Erbaum Associates, Publishers, London.

[5] Davis, S. F., Drinan, P. P., \& Gallant, T. B. 2007. Cheating in School, Willey-Blackwell, United Kingdom

[6] Anderman, E. M \& Midgley, C., 2004, Changes in Self- Reprted Cheating Across The Transition from Middle School to High School, Contemporary of Educational and Counseling Psychology, 29: 499

[7] Anderman, E. M., Cupp, P. K \& Lane D., 2010, Impulsivity and Cheating, The Journal of Experimental Education, 78: 135

[8] Vinsk, E. J., and Tryon, G., 2009, Study of Cognitive Dissonance Intervention to Address High School Students' Cheating Attitudes and Behaviors, Ethics \& Behavior, 19(3): 218-226

[9] Tas, Y and Tekkaya, C, 2010, Personal and Contextual Factors Associated with Students' Cheating in Science, The Journal of Experimental Education, Vol 78, p440-463

[10] Houser, B. B, 1982, Student Cheating and Attitude: A Function of Classroom Control technique, Contemporary Educational Psychology 7, 113-123

[11] Semerci, C, 2006, The Opinion of Medicine Faculty Students regarding Cheating in relation to Kohlberg's Moral development Concept, Social Behavior and personality, 34(1), 41-50

[12] Murdock, T. B, Hale, N. M. And Weber, M. J., 2001, Predictors of Cheating among Early Adolescents : Academic and Social Motivation, Contemporary Educational Psikology 26, 96-115

[13] Ledwith, A and Risquez, A, 2008, Using Anti-Plagiarism Software to Promote Academic Honesty in The Context of Peer Reviewed Assigment, Studies in Higher Education, Vol.33, No.4, p371-384

[14] Smith, Jimmie, N., Nolan, Rebecca, F., Dai \& Yong, 1998, Faculty Perception of Student Academic Honesty, College Student Journal, $32: 2$

[15] Grijalva, Therese C., Nowel, Clifford, Kerkvliet, Joe, 2006, Academic Honesty and Online Courses, College Student Journal, Vol 40: 1
[16] Payan, J., Reardon, J. \& McCorkle, D, E. 2010. The Effect of Culture on Academic Honesty of Marketing and Bussiness Students, Journal of Marketing Education, 32: 275.

[17] Firmin, M. W., Burger, A., Blosser, M., 2006, Affective Responses of Students Who Witness Classroom Cheating, Educational Research Quarterly, 32.3

[18] Davy, J. A., Kincaid, j. F., Smith, k. J. \& Trawick, M. A., 2007, An Examination of the Role of Attitudinal Characteristics and Motivation on the Cheating Behavior of Bussiness Students, Ethics \& Behavior, 17 (3)

[19] Rourke, J. O., Barnes, J, Deaton, a., Fulks, K., Ryan K. Rettinger, D, A., 2010, Imitationj Is the Suncerest form of Cheating: The Influence of Direct Knowledge and attitudes on Academic Dishonesty, Ethics \& Behavior, 20(1)

[20] Staat, S., Hupp, J M. \& Hagley, A M, 2006, Honesty and Heroes: A Positive Psychology View of Heroism and Academic Honesty, The Journal of Psychology, 142(4), 357-372

[21] Braun, R.L. \& Stallworth, H. L., 2009, The Academic Honesty Expectations Gap: an Analysis of Accounting Student and Faculty Perspectives, The Accounting Educators' Journal, 19: 127

[22] Deranek, J \& Parnther, C, 2015, Academic Honesty and The New Technological Frontier, The Hilltop Review Paper, Vol 8, Article 4

[23] Eisenberg, J. 2004. To Cheat or Not to Cheat: Effects of Moral Perspective and Situational Variables on Students' Attitudes, Journal of Moral Education, 33:2.

[24] Shaftel, F. R. and Shaftel, G., 1982 Role Playing in The Curriculum, Prantice Hall, Inc, United States of America

[25] Joyce, B \& Weil, M, 1996, Model of Teaching $5^{\text {th }}$ Edition, Allyn \& Bacon, United State

[26] Salkind, N. J, 2006, Exploring Research, Pearson International Edition, New Jersey, Pearson Education Inc

[27] Santrock, J. W. 2004. Educational Psychology, (2 $2^{\text {nd }}$ ed), New York: Mc Graw-Hill. 